\title{
ПРОБЛЕМА ДИСКРИМИНАЦИИ ПРАВ ЖЕНЩИН В НАУЧНО-ОБРАЗОВАТЕЛЬНОЙ СФЕРЕ
}

\author{
Н.Н. Сяврикова \\ Московский гуманитарный университет
}

\begin{abstract}
Аннотация: В статье рассматривается проблема дискриминации женщин в научнообразовательной сфере. Раскрываются этапы становления женского образования в России.

Ключевые слова: женское образование, женское учебное заведение, высшее образование
\end{abstract}

\section{THE PROBLEM OF DISCRIMINATION OF WOMEN'S RIGHTS IN THE SCIENTIFIC AND EDUCATIONAL SPHERE}

\author{
N.N. Syavrikova \\ Moscow University for the Humanities
}

\begin{abstract}
The article examines the problem of discrimination against women in the scientific and educational sphere. The stages of the formation of female education in Russia are revealed.
\end{abstract}

Keywords: women's education, women's educational institution, higher education

На сегодняшний день женщины в России, как и в большинстве других стран, имеют свободный доступ к получению высшего образования и к науке на той же правовой основе, что и мужчины. Но так было не всегда. Статус и социальная роль женщины на различных этапах общественного развития во многом зависит от типа общества, а также от того, насколько материально и духовно развита культура.

К концу XX в. женщины-студентки составляли уже практически половину от общего числа всех студентов в России, а, значит, и половину кадрового потенциала. Данная пропорция числа женщин и мужчин в системе высшего образования и науки в России воспринимается как вполне естественное явление. Но если мы будем рассматривать вопрос под историческим углом, то заметим, что участие женщин в научно-образовательной сфере было далеко не всегда таким активным (Гуревич, 2009).

Когда-то общественное мнение считало - женщина должна находиться дома, в окружении отца или мужа, и образование может только испортить ее характер. Т.е. очевиден был неравный социальный статус женщины.

Однако, еще во времена Древней Руси, а именно - 1086 г. в Киеве, княгиня Анна Всеволодовна открыла девичье училище при Андреевском монастыре. Но общий упадок культурной жизни Древней Руси в результате татаро-монгольского нашествия отразился и на образовании.

Именно монастыри сыграли роль хранителей и распространителей образования, хоть и с религиозным уклоном, но в школах при монастырях 
и храмах обучались грамоте, в основном, мальчики. А образование девочек в женских монастырях сводилось, в основном, к обучению шитью, вышивке, кружевоплетению и другим женским рукоделиям.

Такая ситуация оставалась вплоть до XVIII в. и изменения произошли лишь тогда, когда Петр I вознамерился создать в России первое женское учебно-воспитательное заведение. Планам царя-реформатора в этой области не суждено было сбыться, но ведущим направлением в развитии женского образования петровской эпохи и последующих четырех десятилетий являлось домашнее образование девушек, а так же - создание частных школ и пансионов для девочек.

Под влиянием тенденций того времени, семьи аристократов были вынуждены нанимать для обучения дочерей иностранцев, тратить деньги на покупку книг и учебников, заботиться о впечатлении, которое произведут их дочери, когда их вывезут в свет.

Девушки обучались хорошим манерам, танцам, рисованию, рукоделиям, умению поддержать беседу, иностранным языкам. Эти навыки стали цениться в девушках, а со временем появилась потребность и в получении начальных знаний по некоторым наукам - истории, географии, литературе. Но это относилось к представительницам лишь высших слоев общества.

Даже несостоятельные дворяне в своем большинстве, не говоря уж о крестьянских семьях, образование дочерей считали излишним (Константинов, Медынский, Шабаева, 2002).

Власть всерьез озаботилась организацией женского образования в царствование Екатерины II. «Воспитательное общество благородных девиц» было открыто 28 июня 1764 г. в Петербурге, в Воскресенском Новодевичьем монастыре, иначе - в Смольном монастыре. Оно стало первым в России государственным женским средним учебным заведением закрытого типа. В нем 12 лет обучались лишь 200 воспитанниц, а принимали в этот институт девочек с 6 лет. Причем, родители должны были предоставить документы, подтверждающие высокое дворянское происхождение. Позже подобные «Институты благородных девиц» появились и в других городах России, например, в Москве.

$\mathrm{C}$ того времени и практически до начала XX в. дискриминация женщин в сфере высшего образования практически осуществлялась на официальном уровне, такой была в отношении к женщинам сама государственная политика. В течении многих лет государственные высшие учебные заведения предназначались исключительно для лиц мужского пола и жестко регулировались по половому признаку. Власть была принципиальной противницей совместного обучения мужчин и женщин (Евстратова, Никонов, 2007).

Официально вопрос о том, чтобы разрешить женщинам посещать университеты был рассмотрен Министерством народного просвещения в 1863 г. 
Предварительно Министерством был сделан запрос в университеты относительно того, могут ли женщины допускаться к слушанию лекций. Большинство университетов поддержало эти предложения.

Против выступили лишь Московский и Дерптский университеты, аргументируя свой протест тем, что совместное обучение окажет плохое воздействие на студентов-мужчин.

Было решено не допускать совместного слушания лекций ни под каким предлогом, потому что оно может оказывать плохое влияние на успешный ход занятий молодых людей, обучающихся в университете.

Сторонники женского образования предлагали допустить женщин к обучению официально, со всеми правами и обязанностями, а также с возможностью присваивать им ученую степень. (Днепров, Усачева, 2009).

Компромисс был предложен Петербургским и Казанским университетами допустить к обучению женщин как вольнослушателей. При этом в Петербургском университете считали, что диплом должен давать женщинам только право на медицинскую практику и работу преподавателем в высших учебных заведениях, тоже исключительно женских.

В 1859 г. для женщин, которые стремились к получению знаний, открыл двери Петербургский университет. Огромное количество женщин в качестве вольнослушательниц приходили на лекции Киевского и Харьковского университетов.

Одной из распространенных форм обучения тогда стали и так называемые «летучие университеты» на частных квартирах: там читались бесплатные лекции ведущими профессорами. Но, к сожалению, в 1864 г. женщин не только не принимали в число студенток, но и не допускали к слушанию лекций. Прекратились даже попытки говорить о женском высшем образовании и на законодательном уровне, и в печати (Драч, 2006).

Отмена крепостного права привела к обнищанию значительной части дворянства, которое осталось без средств к существованию. И если мужчинадворянин мог решить эту проблему, поступив на службу, то для женщин возможности самостоятельного заработка были крайне ограничены.

В тех поместьях, которым удалось избежать разорения, женщины также были лишены привычного круга обязанностей по управлению домашним хозяйством и крестьянами, т.е., можно сказать, оказались без работы, что приводило к неудовлетворенности своим социальным положением и усиливало приверженность к популярным идеям о необходимости служения обществу (Кармин, 2007).

Сама жизнь требовала от русской интеллигентной девушки участия в общественном труде. Но также сильны были и духовные побуждения молодых девушек, которые стремились к светлым идеалам и свободе личности. Итак, 
высшее женское образование стало ощущаться не как прихоть или роскошь, а как реальная потребность и острая необходимость. (Каптерев, 1889).

Система женского образования формировалась на фоне столкновения взглядов сторонников женского равноправия и консерваторов, которые отрицали необходимость замены закрытых сословных женских учреждений иными учебными заведениями.

Один из аргументов заключался в том, что образование не должно быть многогранным, поскольку его задача - готовить женщину исключительно к роли супруги и матери, а не к профессиональной деятельности.

Преобладание подобных аргументов в обществе побудило сторонников среднего и высшего образования рассмотреть вопрос о том, какими именно знаниями должна обладать женщина для того, чтобы быть хорошей матерью и каким образом следует учитывать этот фактор при разработке программ обучения в женских учебных заведениях.

Общая закономерность развития образования в России в целом, проявилась в исторической жизни российской женской средней школы. Первый ее жизненный цикл, который охватил 1760-1850-е годы, протекал в рамках господствующего, непререкаемого влияния государства.

Второй цикл, начавшийся в конце I850 гг., был ознаменован опережающим «выпадением» значительной части средней женской школы из государственной сферы, обретением ею юридически и фактически общественного, неправительственного характера.

Власть вынуждена была на первых порах считаться с этим. Не случайно в объяснительной записке к Положению о женских училищах 1860 г. отмечалось, что эти училища имеют «характер общественных учебных заведений» (Бордовская, Реан, 2006).

По факту, открытая всесословная средняя женская школа, созданная в конце 1850-1860 гг., стала первым в России проектом общественных образовательных усилий. Она представляла собой абсолютно новую социально-педагогическую модель построения женского образования, отвергавшую три основные установки той государственной политики, которая была ранее в этой сфере: жесткую сословность, закрытый характер учебных заведений и полное устранение влияния на них общественности.

Количество желающих получать образование возрастало. Общественный напор был достаточно силен, и на рубеже 60-70 гг. сначала в Петербурге и в Москве, а затем и в других городах стали создаваться высшие женские курсы. (Егоров, 2008).

Кроме политических деятелей, против того, чтобы женщины получали высшее образование и занимались наукой, выступали и ученые, но уже по другим соображениям. «Многие мужчины, особенно в ученых кругах, - писал 
А. Бебель, - выступают против университетского образования женщин потому, что они боятся принижения науки, престиж которой должен будто бы пострадать, если женщины получат возможность посвятить себя научным занятиям.

Они видят в научных занятиях особую привилегию, которая должна быть доступна лишь избранникам мужского пола» (Агамова, 2009). Таким образом, как официальная позиция мужчин в государственном аппарате, так и мнение мужчин в российском научном сообществе долгое время препятствовали полноправному включению женщин в систему высшего образования и науки. Однако были и исключения.

Среди части либерально настроенной российской профессуры наблюдались и те, кто был обеспокоен сложившейся ситуацией и показывали стремление к развитию равноправного участия женщин в научно-образовательной сфере.

\section{СПИСОК ЛИТЕРАТУРЫ}

Агамова Н.С. (2009) Российские женщины в науке и высшей школе: историконаучные и науковедческие аспекты. М.: Директ-Медиа, 39 с.

Бордовская Н.В., Реан А.А. (2006) Педагогика. СПб.: Питер. 304 с.

Гуревич П.С. (2009) Культурология. М.: ВЛАДОС. 278 с.

Драч Г.В. (2006) Учебный курс по культурологии. Ростов- на- Дону. 608 с.

Днепров Э.Д., Усачева Р.Ф. (2007), Женское образование в России. Учеб. пособие для студ. вузов. М.: Дрофа. 286 с.

Днепров Э.Д., Усачева Р.Ф. (2010) Среднее женское образование в России. Учеб. пособие, М. 273 с.

Евстратова А.И., Никонов И.И. (2007) Развитие высшего женского образования в России в XIX веке //Женщины в отечественной науке и образовании. Иваново. C. 33-35.

Егоров С.Ф. (2008) История педагогики в России: Хрестоматия. 2-е изд. М.: Академия. $400 \mathrm{c}$.

Кармин А.С. (2007) Культурология. СПб.: Питер. 784 с.

Каптерев П.Ф. (1889) Идеалы женского образования // Образование. №1.

Константинов Н.А., Медынский Е.Н., Шабаева М.Ф. (2002) История педагогики. М.: Просвещение. 447 с.

Сяврикова Нонна Николаевна - студентка 3 курса кафедры педагогики и психологии высшей школы Московского гуманитарного университета. Научный руководитель: Профессор кафедры педагогики и психологии высшей школы Л.В. Романюк. Адрес: 111395, Россия, г. Москва, ул. Юности, д. 5. Тел.: +7 (915) 51875-53. Эл. адрес: n.nikolaevna55@mail.ru

Syavrikova Nonna Nikolaevna - 3rd year student, Department of Pedagogy and Psychology of Higher School, Moscow University for the Human- 
ities. Scientific adviser: Professor of the Department of Pedagogy and Psychology of Higher School L.V. Romanyuk. Address: 111395, Russia, Moscow, st. Yunosti, 5. Tel .:+7 (915)-518-75-53. Email address: n.nikolaevna55@mail.ru

Сяврикова Н.Н. Проблема дискриминации прав женщин в научно-образовательной сфере // Научные труды Московского гуманитарного университета. 2020. №6. С. 78-83. DOI: https://www.doi.org/10.17805/trudy.2020.6.14 